\title{
Heavy-Duty Alpha-Cellulose-Filled Melamine Tableware
}

\author{
A RECORDED VOLUNTARY STANDARD OF THE TRADE
}

\section{COMMODITY STANDARDS}

Simplified Practice Recommendations and Commercial Standards are developed by manufacturers, distributors, and users in cooperation with the Commodity Standards Division of the Office of Industry and Commerce, Bureau of Foreign and Domestic Commerce, and with the National Bureau of Standards.

The purpose of Simplified Practice Recommendations is to eliminate avoidable waste through the establishment of standards of practice for stock sizes and varieties of specific commodities that currently are in general production and demand. The purpose of Commercial Standards is to establish standard methods of test, rating, certification, and labeling of commodities, and to provide uniform bases for fair competition.

The adoption and use of a Simplified Practice Recommendation or a Commercial Standard is voluntary. However, when reference to a Commercial Standard is made in contracts, labels, invoices, or advertising literature, the provisions of the standard are enforceable through usual legal channels as a part of the sales contract.

A Simplified Practice Recommendation or a Commercial Standard originates with the proponent industry. The sponsors may be manufacturers, distributors, or users of the specific product. One of these three elements of industry submits to the Commodity Standards Division the necessary data to be used as the basis for developing a standard of practice. The Division, by means of assembled conferences or letter referenda, or both, assists the sponsor group in arriving at a tentative standard of practice and thereafter refers it to the other elements of the same industry for approval or for constructive criticism that will be helpful in making any necessary adjustments. The regular procedure of the Division assures continuous servicing of each effective Simplified Practice Recommendation and Commercial Standard, through review and revision, whenever, in the opinion of the industry, changing conditions warrant such action. Simplified Practice Recommendations and Commercial Standards are printed and made available by the Department of Commerce through the Government Printing Office and the Department of Commerce field offices.

\section{UNITED STATES DEPARTMENT OF COMMERCE}

\section{Charles Sawyer, Secretary}




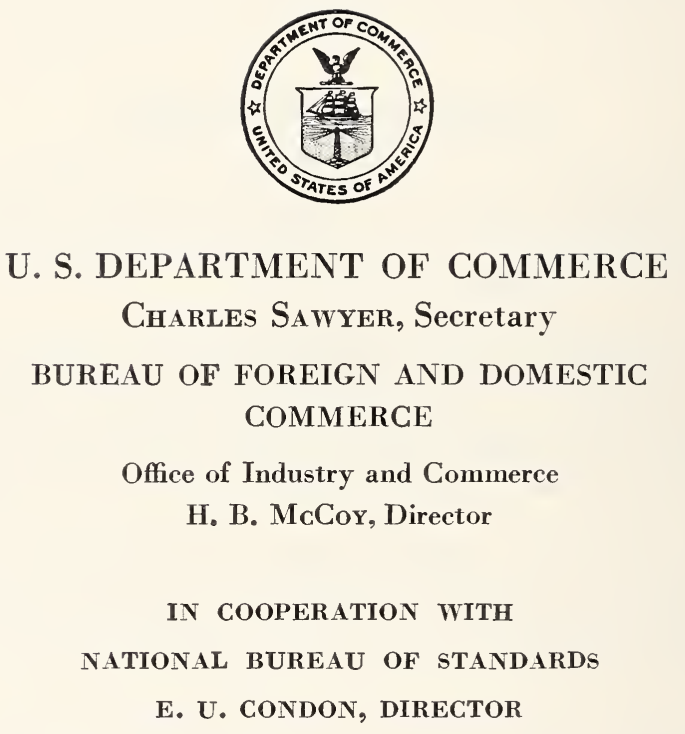




\section{Heavy-Duty Alpha-Cellulose-Filled Melamine Tableware}

[Effective From December 15, 1950]

\section{PURPOSE}

1.1 The purpose of this commercial standard is to foster maintenance of the quality of heavy-duty alpha-cellulose-filled melamine tableware, and to provide a nationally recognized specification for the information of producers, distributors, and users.

\section{SCOPE}

2.1 This commercial standard covers chemical and physical properties and methods of test for heavy-duty tableware molded from alphacellulose-filled melamine materials. The materials used are composed of melamine-formaldehyde resin combined with alpha-cellulose as the filler. An identifying hallmark and recommended statement of compliance are included.

\section{REQUIREMENTS}

3.1 Thickness.-Tableware con forming to this commercial standard shall have a thickness of not less than 0.100 inch over not less than 90 percent of the surface area, and the remainder shall not be less than 0.090 inch in thickness.

3.2 Finish.- The surface of all tableware shall have a high luster produced by molding, and not by the application of finish or protective coating or lacquer, or by the use of other adulterants. Flash or parting lines only shall be buffed to a high polish.

3.3 Resistance to boiling sulfuric-acid solution.-When tested in accordance with paragraph 4.2, tableware shall show no chalking and/or loss of gloss that is readily perceptible without close examination.

3.4 Resistance to boiling water.-When tested in accordance with paragraph 4.3, the tableware shall not develop cracks, or show surface chalking or any other defects that might impair the serviceability or appearance of the tableware.

3.5 Resistance to dry heat.-When tested in accordance with paragraph 4.4 , the tableware shall show no cracks.

\section{METHODS OF TEST}

4.1 The methods of test are especially designed so that they can be conducted by purchasers, distributors, or molders without the use of costly equipment, and by personnel that need not be specially trained. Meeting these tests is evidence of proper molding. 
4.1.1 Five specimens chosen at random shall be tested to determine conformance of tableware with each of the requirements of section 3 . If one of the five specimens fails to meet the requirements of a given test, five additional specimens shall be subjected to that test, all of which shall be required to pass the test in order to indicate conformance of the tableware with this commercial standard. If more than one of the original five specimens for a given test fails, the tableware shall be reported as failing to conform with this commercial standard.

4.2 Sulfuric acid test.

4.2.1 Materials:

(a) Aqueous solution of sulfuric acid 0.8 percent by weight. This solution can be obtained from a local druggist or chemical supply house.

(b) Porcelain-enameled or stainless-steel pail, with cover, about 2- to 3-quart capacity (2000 to $3000 \mathrm{ml}$ ). Enameled ware must not be used if the inside surface is chipped, exposing bare metal.

(c) Heater, preferably a gas burner of about 4 to 5 inches in diameter. In any event, it should have sufficient capacity to keep the acid solution boiling fairly vigorously.

4.2.2 Procedure.-Five untested specimens shall be used for this test. From the molding to be tested, cut a cross-section strip about 3 inches wide, if a plate, dish, or saucer is being tested. If testing a cup, cut a section of about one-half of the molded part, taking for the test that part which includes the handle. The entire piece of tableware may be used if it is desired not to destroy it by cutting.

Heat to boiling a fresh portion of acid solution, keeping the container covered. Immerse the test piece(s) and re-cover the vessel. Keep boiling. Remove test piece (s) after 10 minutes, \pm 0.5 minute, rinse in cold water, and dry. Inspect for conformance with paragraph 3.3 .

4.2.3 Precautions.

4.2.3.1 The acid solution is corrosive, and care should be taken that it is not splashed on one's person or clothing, or about the premises.

4.2.3.2 Use fresh acid solution for each test run.

4.2.3.3 The solution must be kept boiling during the 10 minutes of the test. If too many test pieces are put in at once, the solution will be cooled to such an extent that it will stop boiling, thus endangering the accuracy of the test. By trial and error, one can determine the maximum number of parts which can be properly tested at one time.

4.2.3.4 Test pieces can be attached to fairly heavy cord or string, and be removed by this means when the test is completed.

4.2.3.5 Test pieces should be kept separated during boiling so that the acid bath has free access to all surfaces.

4.2.3.6 Dispose of waste acid solution by allowing it to cool, then flushing it down the toilet, using plenty of water.

$4.3^{\circ}$ Resistance to boiling water.-Five untested specimens shall be used for this test. Each sample of tableware shall be placed in boiling water for 30 minutes, removed, and allowed to stand for 1 hour at room temperature. This cycle shall be immediately repeated three times to give a total of four such cycles. The tableware shall be allowed to stand for 48 hours in air at room temperature. In cases of 
dispute, a temperature of $23^{\circ} \pm 1.1^{\circ} \mathrm{C}\left(73.5^{\circ} \pm 2^{\circ} \mathrm{F}\right)$, and a relative humidity of 50 percent \pm 4 percent shall be maintained. Inspect the tableware for conformance with paragraph 3.4.

4.4 Resistance to dry heat.-Five untested specimens shall be used for this test. Place the tableware in a circulating-air oven for 8 hours at $170^{\circ} \mathrm{F}$. Cool to room temperature, and inspect for conformance with paragraph 3.5.

\section{MARKING AND IDENTIFICATION}

5.1 Hallmark.-Pieces of heavy-duty alpha-cellulose-filled melamine tableware may carry the hallmark shown in figure 1, which shall constitute the manufacturer's declaration of compliance with this commercial standard.

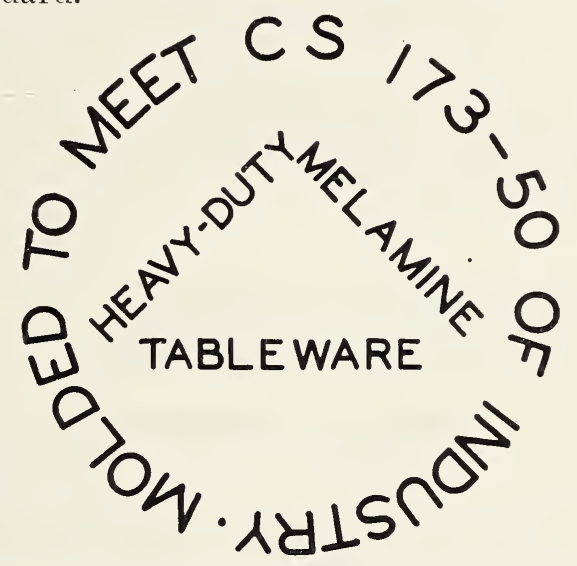

FIGURE 1. Enlarged reproduction of hallmarl.

5.2 Marking.-In order that purchasers may be assured that pieces of heavy-duty alpha-cellulose-filled melamine tableware purchased actually comply with all requirements of this commercial standard, it is recommended that manufacturers include the following statement in conjunction with their name and address on labels, invoices, sales literature, etc. :

This (these) article ( $\mathrm{s}$ ) of heary-duty alpha-cellulose-filled melamine tableware complies (comply) with Commercial Standard CS173-50, as dereloped by the trade under the procedure of the Commodity Standards Division, and issued by the U. S. Department of Commerce.

5.3 When available space on labels is insufficient for the full statement in legible type, an abbreviated statement, as follows, is recommended :

Complies with CS173-50, as developed by the trade, and issued by the U. S. Department of Commerce.

\section{EFFECTIVE DATE}

6.1 Having been passed through the regular procedure of the Commodity Standards Division, and approved by the acceptors hereinafter listed, this commercial standard was issued by the United States Department of Commerce, effective from December 15, 1950.

Edwiñ W. ELY, Chief, Commodity Standards Division. 
On April 26, 1949, the Society of the Plastics Industry, Inc., requested the cooperation of the National Bureau of Standards in the establishment of a commercial standard for heavy-duty alpha-cellulose-filled melamine tableware.

Following receipt of this request by the Bureau, copies of a proposed commercial standard for heavy-duty alpha-cellulose-filled melamine tableware, endorsed by the proponent organization, were circulated to selected representatives of manufacturers, distributors, purchasers, testing laboratories, and Government agencies for advance comment. The specification was adjusted in accordance with majority viewpoint as indicated by the comment.

With the unqualified endorsement of a number of interested organizations, the recommended commercial standard was submitted to the trade for written acceptance on September 18, 1950 . Having received acceptances in writing estimated to represent a satisfactory majority, announcement was issued on November 15, 1950, that the standard would become effective for new production on December 15,1950 .

Project Manager: F. W. Reynolds, assisted by H. A. Bonnet, Commodity Standards Division, Office of Industry and Commerce.

Technical Advisers: Dr. G. M. Kline and F. W. Reinhart, Organic and Fibrous Materials Division, National Bureau of Standards.

\section{STANDING COMMITTEE}

The following individuals comprise the membership of the standing committee, which is to review, prior to circulation for acceptance, revisions proposed to keep the standard abreast of progress. Comment concerning the standard and suggestions for revision may be addressed to any member of the committee or to the Commodity Standards Division, Office of Industry and Commerce, U. S. Department of Commerce, which acts as secretary for the committee.

Charies H. Frantz, Plastics Manufacturing Co., 825 Trunk Avenue, Dallas 10, Tex. (chairman).

A. L. Alves, The Watertown Manufacturing Co., 100 Echo Lake Road, Watertown, Conn.

George K. Scribner, Boonton Molding Co., Boonton, N. J.

George V. Goulder, International Molded Plastics, Inc., 4384 West Thirty-fifth Street, Cleveland 9, Ohio.

Lloyd T. Moone, Applied Plastics Division, Keystone Brass Works, Inc., 1103 West Twelfth Street, Erie, Pa.

R. H. Cunningham, Hemco Plastics Division, The Bryant Electric Co., Bridgeport 2, Conn.

Willia H. MacHale, American Cyanamid Co., 30 Rockefeller Plaza, New York, N. Y.

M. H. Brgelow, Plaskon Division, Libbey-Owens-Ford Glass Co., 2112 Sylvan Avenue, Toledo 6, Ohio.

Parker D. Perry, Parker D. Perry, Inc., 729 Boylston Street, Boston 16, Mass. George E. Weigl, George E. Weigl Co., 230 Fifth Avenue, New York, N. Y.

Alta Atrinson, Teachers College, Columbia University, New York, N. Y. (representing American Dietetic Association).

J. S. Fassetr, Service Department, American Hotel Association, 221 West Fiftyseventh Street, New York, N. Y.

Franklin D. Carr, Waukesha Memorial Hospital, Waukesha, Wis., Leonard P. Goudy, 18 East Division Street, Chicago 10, Ill. (alternate), (representing Amelican Hospital Association). 


\section{ACCEPTANCE OF COMMERCIAL STANDARD}

If acceptance has not previously been filed, this sheet properly filled in, signed, and returned will provide for the recording of your organization as an acceptor of this commercial standard.

Date_..-_.

Commodity Standards Division,

Office of Industry and Commerce,

U. S. Department of Commerce,

Washington 25, D. C.

Gentlemen :

We believe that the Commercial Standard 173-50 constitutes a useful standard of practice, and we individually plan to utilize it as far as practicable in the

Production $^{1} \quad$ distribution $^{1} \quad$ purchase $^{1} \quad$ testing $^{1}$

of heavy-duty alpha-cellulose-filled melamine tableware. The reserve the right to depart from it as we deem advisable.

We understand, of course, that only those articles which actually comply with the standard in all respects can be identified or labeled as conforming thereto.

Signature of authorized officer

(In ink)

(Kindly typewrite or print the following lines)

Name and title of above officer

Organization

(Fill in exactly as it should be listed)

Street address

City, zone, and State

${ }^{1}$ Underscore which one. Please see that separate acceptances are filed for all subsidiary companies and affiliates which should be listed separately as acceptors. In the case of related interests, trade associati ns, trade papers, etc., desiring to record their general support, the words "General support" should be added after the signature. 


\section{TO THE ACCEPTOR}

The following statements answer the usual questions arising in connection with the acceptance and its significance:

1. Enforcement.-Commercial standards are commodity specifications voluntarily established by mutual consent of those concerned. They present a common basis of understanding between the producer, distributor, and consumer and should not be confused with any plan of governmental regulation or control. The United States Department of Commerce has no regulatory power in the enforcement of their provisions, but since they represent the will of the interested groups as a whole, their provisions through usage soon become established as trade customs, and are made effective through incorporation into sales contracts by means of labels, invoices, and the like.

2. The acceptor's responsibitity.-The purpose of commercial standards is to establish, for specific commodities, nationally recognized grades or consumer criteria, and the benefits therefrom will be measurable in direct proportion to their general recognition and actual use. Instances will occur when it may be necessary to deviate from the standard and the signing of an acceptance does not preclude such departures; however, such signature indicates an intention to follow the commercial standard where practicable in the production, distribution, or consumption of the article in question.

3. The Department's responsibility.-The major function performed by the Department of Commerce in the voluntary establishment of commercial standards on a Nation-wide basis is fourfold : first, to act as an unbiased coordinator to bring all interested parties together for the mutually satisfactory adjustment of trade standards; second, to supply such assistance and advice as past experience with similar programs may suggest; third, to canvass and record the extent of acceptance and adherence to the standard on the part of producers, distributors, and users; and fourth, after acceptance, to publish and promulgate the standard for the information and guidance of buyers and sellers of the commodity.

4. Announcement and promulgation.-When the standard has been endorsed by a satisfactory majority of production or consumption in the absence of active valid opposition, the success of the project is announced. If, however, in the opinion of the standing committee or of the Department of Commerce, the support of any standard is inadequate, the right is reserved to withhold promulgation and publication. 


\section{ACCEPTORS}

The organizations listed below have individually accepted this standard for use as far as practicable in the production, distribution, testing, purchase, or use of heavy-duty alpha-cellulose-filled melamine tableware. In accepting the stand. ard they reserved the right to depart from it as they individually deem advisable. It is expected that articles which actually comply with the requirements of this standard in all respects will be regularly identified or labeled as conforming thereto, and that purchasers will require such specific evidence of conformity.

\section{ASSOCIATIONS \\ (General Support)}

American Hotel Association, New York, N. Y. Society of the Plastics Industry, Inc., New York, N. Y.

\section{FIRMS, HOSPITALS, AND OTHER INTERESTS}

Albuquerque Indian Sanatorium, Albuquerque, N. Mex.

American Cyanamid Co., Calco Chemical Division, Bound Brook, N. J.

American Cyanamid Co., New York, N. Y (General support.)

American Insulator Corp., New Freedom, Pa. Applied Plastics Division, Keystone Brass Works, Inc., Erie, Pa.

Arkansas Baptist Hospital, Little Rock, Ark. Ball Memorial Hospital, Muncie, Ind.

Bayamon District Hospital, Bayamon, Puerto Rico.

Baylor Hospital, Dallas, Tex.

Beloit Municipal Hospital, Beloit, Wis.

Beth Israel Hospital, Boston, Mass.

Bethesda Hospital, Cincinnati, Ohio

Blodgett Memorial Hospital, Grand Rapids, Mich.

Bolta Co. The, Lawrence, Mass.

Boonton Molding Co.. Boonton, N. I

Boulder (Colorado) Sanitarium \& Hospital, Boulder, Colo.

Brooklyn Hospital, The, Brooklyn, N. Y.

Bryant Electric Co., The, Hemco Plastics Division, Bridgeport, Conn.

Bryn Mawr Hospital, The, Bryn Mawr, Pa.

Buffalo General Hospital, Buffalo, N. Y.

Burlington Hospital, Burlington, Iowa

Butterworth Hospital, Grand Rapids, Mich.

California Hospital, The, Los Angeles, Calif.

Central Maine Sanatorium, Fairfield, Maine.

Central State Hospital, Petersburg, Va.

Charles A. Dean Memorial Hospital, Greenville Junction, Maine.

Chestnut Hill Hospital, Philadelphia, Pa.

Chicago, City of, Bureau of Lunch Rooms, Board of Education, Chicago, Ill.

Children's Convalescent Home, Cincinnati, Ohio

Children's IIospital, The, Washington, D. C

Children's Hospital of Michigan, Detroit, Mich.

Church Home and Hospital, Baltimore, Md. Cincinnati, City of, Department of Purchasing, Cincinnati, Ohio

Citizens General Hospital, New Kensington, $\mathrm{Pa}$.

City Memorial Hospital, Winston-Salem, N. C.

Colorado, University of, Department of Medicine, Denver, Colo.

Community General Hospital, Reading, Pa.

Community Hospital, San Mateo, Calif.

Community Hospital, The, Berea, Ohio
Crouse-Irving Hospital, Syracuse, N. Y.

Dayton State Hospital. Dayton, Ohio

Delaware Hospital, The, Inc., Wilmington, Del.

Denver Bureau of Health and Hospitals, Denver, Colo.

Detroit Tuberculosis Sanatorium, Detroit, Mich.

Devine Foods, Inc., Chicago, Ill.

DuBois Co., The, Cincinnati, Ohio

Dura-Ware, Beverly, N. J.

Easton Hospital, Easton, $\mathrm{Pa}$

Edgewater Hospital, Chicago, Ill.

Ellis Hospital, Schenectady, N. Y.

Evanston Hospital Association, Evanston, III.

Fairview Hospital, Minneapolis, Minn.

Genesee Hospital, The, Rochester, N. Y.

Gernantown Hospital, Philadelphia, Pa.

Glens Falls Hospital, Glens Falls, N. Y.

Grace Hospital, Cleveland, Ohio

Grace Hospital, The, Detroit, Mich.

Grady Memorial Hospital, Atlanta, Ga.

Grafton State Hospital, North Grafton, Mass.

Grandview Hospital, LaCrosse, Wis.

Grant Hospital, Columbus, Ohio

Hackensack Hospital Association, Hackensack, N. J

Hahnemann Hospital, Scranton, Pa.

Hamot Hospital, Erie, Pa.

Harlem Valley State Hospital, Wingdale, N. $Y$.

Harper Hospital, The, Detroit, Mich.

Healthwin Hospital, South Bend, Ind.

Henry County Hospital, New Castle, Ind.

Henry Ford Hospital, Detroit, Mich.

Herrick Memorial Hospital, Berkeley, Calif.

Hillerest Memorial Hospital, Tulsa, Okla.

Hospital for Children and. Training School for Nurses, San Francisco, Calif.

Hospital of the Good Shepherd of Syracuse University, Syracuse, N. Y.

Huntington Memorial Hospital, Pasadena, Calif.

International Molded Plastics, Inc., Cleveland. Ohio

Iowa Methodist Hospital-Raymond Blank Memorial Hospital for Children, Des Moines, Iowa

J. J. McCook Memorial IIospital, Hartford, Conn.

Jefferson Hospital, Philadelphia, Pa.

Jewish Hospital, The, Cincinnati, Ohio

Jewish Memorial Hospital, New York, N. Y.

Kahler Corp., The, Rochester. Minn.

Kansas City, City of, Kansas City, Mo.

Kansas. University of, Medical Center, Kansas City, Kans.

Lake County Memorial Hospital, Painesville, Ohio.

Lankenau Hospital, The, Philadelphia, Pa.

Los Angeles, City of, Los Angeles, Calif.

Los Angeles County General Hospital, Los Angeles, Calif.

Lowell General Hospital, Lowell, Mass. 
Lutheran Deaconess IIospital, Chicago, Ill. Maple Leaf Ilastics Limited, Toronto, Ontario, Canada

Mary Fletcher Hospital, Burlington, Vt.

Meadowbrook Hospital, Hempstead, N. Y.

Melrose Hospital Association, Melrose, Mass.

Memorial Hospital, Philadelphia, Pa.

Memorial Hospital, The, Pawtucket, R. I.

Memorial Hospital of South Bend, South Bend. Ind.

Mercy Hospital, Des Moines, Iowa

Methodist Hospital of Gary, Inc., Gary, Ind.

Michael Reese Hospital, Chicago, Ill.

Iilwaukee County Hospital, Milwaukee, Wis.

Morristown Memorial Hospital, Morristown, N. J.

Mound Park Hospital, St. Petersburg, Fla.

Mount Sinai Hospital, The, New York, N. Y.

Iountainside Hospital, Montclair, N. J.

Nashville General Hospital, Nashville, Tenn.

Nathan Littauer Iospital, Gloversville, N. Y.

National Jewish Hospital at Denver, Denver, Colo.

Nenrological Hospital Association, Kansas City, Mo.

New Haven Board of Education, New Haven, Conn.

Newark City Hospital, Newark, N. J.

Newark, City of, Division of Central Pur chase, Newark, N. J.

Nichols Plastic \& Engineering Co., Los Angeles, Calif.

Norfolk County Hospital, South Braintree, Mass.

North Country Community Hospital, Jihe, Glen Cove, N. Y.

North Dakota State Tuberculosis Sanatorium, San Haven, N. Dak.

Northern Industrial Chenical Co., South Boston, Mass.

Norton Memorial Infirmary, Louisville, $\mathrm{Ky}$.

Oak Ridge Hospital, Inc., Oak Ridge, Tenn.

Orange Memorial Hospital Unit of the Hospital Center at Orange, Orange, N. J

Oregon State Hospital, Salem, Oreg.

Orthopedic Hospital, Lincoln, Nebr.

Patzig Testing Laboratories, Des Moines, Iowa

Penney, J. C., Co., Inc., New York, N. Y.

Pennsylvania, Commonwealth of, Department of Property \& Supplies, Harrisburg, Pa.

Pennsvlvania Department of Health, Tuberculosis Sanatorium No. 1, South Mountain, $\mathrm{Pa}$.

Perry, Parker D., Inc., Boston, Mass.

Pima County lIospital, Tucson, Ariz.

Plaskon Division, Libbey-Owens-Ford Glass Co., Toledo, Ohio

Plastic Molders, Inc., Chicago, Ill.

Plastics Manufacturing Co., Dallas, Tex.

Presbyterian Hospital, Pittsburgh, Pa.

Prolon Plastics-Division of Pro-phy-lac-tic Brush Co., Florence, Mass.

Providence Lying-in Hospital, Providence, R. I.

Reid Memorial Hospital, Richmond, Ind.

Retreat State Hospital, Retreat, Pa.

Richmond Memorial Hospital, Dreyfus Foundation, Prince Bay, Staten Island, N. Y.

Rochester State Hospital, Rochester, N. Y.

Rockland State Hospital, Orangeburg, N. Y.

Roger Williams General Hospital, Providence, R. I.
St. Agnes Hospital, Philadelphia, Pa.

St. Francis Hospital, San Francisco, Calif.

St. Francis Hospital, Colorado Springs, Culo.

St. Francis Xavier Infirmary, Charleston, S. C

St. Joseph Hospital, South Bend, Ind.

St. Joseph Hospital, Lexington, $\mathrm{Ky}$.

St. Joseph's Hospital, Philadelphia, Pa.

St. Louis Children's Hospital, St. Louis, Mo.

St. Luke's Hospital, Cedar Rapids, Iowa

St. Luke's Hospital, Cleveland, Ohio

St. Luke's Hospital, Davenport, Iowa

St. Luke's Hospital, Jacksonville, Fla.

St. Luke's Hospital, New Bedford, Mass.

St. Luke's Hospital, Newburgh, N. Y.

St. Mary's Hospital, Pierre, S. Dak.

St. Mary's Hospital, Green Bay, Wis.

St. Vincent's Hospital, Portland, Oreg.

St. Vincent's Hospital of the City of New York, New York, N. Y.

St. Vincent's Sanitarium, St. Louis, Mo.

Samaritan Hospital, Troy, N. Y

San Bernardino County Hospital, San Bernardino, Calif.

San Diego County Purchasing Department San Diego, Calif

San Jose Hospital, San Jose, Calif.

Santa Monica Hospital, The, Los Angeles, Calif.

Shawnee Indian Sanatorium, Shawnee, Okla.

Sheppard \& Enoch Pratt Hospital, The, Towson, Md.

South Carolina Sanatorium, State Park, S. C South Shore Hospital, South Weymouth, Mass.

Springfield Hospital, The Springfield, Mass.

State Sanatoriun, Wallum Lake, R. I.

Staten Island Hospital, The, Staten Island, N. $Y$.

Sturdy Memorial Hospital, Attleboro, Mass.

Sunny Acres Cuyahoga County T. B. Hospital, Cleveland, Ohio

Swedish Hospital, The, Seattle, Wash.

Temple University Hospital, Philadelphia Pa.

Uniontown Hospital, Uniontown, Pa.

University Hospital, Augusta, Ga.

Virginia, University of, Charlottesville, Va.

Washington County Hospital, The, Hagerstown, Md

Washoe Medical Center, Reno, Nev.

Watertown Manufacturing Co., The, Watertown, Conn.

Watts Hospital, Durham, N. C.

Wayne County General Hospital and Infirmary, Eloise, Mich.

Weigl, George E., Co., New York, N. Y.

Wesley Long Hospital, Inc., Greensboro, N. C. Wesley Memorial Hospital, Chicago, Ill.

Winnebago State Hospital, Winnebago, Wis. Woman's Hospital, Pittsburgh, Pa.

Woonsocket Hospital. Woonsocket, R. I.

Wyoming County Community Hospital, Warsaw, N. Y.

\section{UNITED STATES GOVERNMENT}

Agriculture, U. S. Department of, Division of Purchase, Sales and Traffic, Washington, D. C.

Army, Department of the, Standards Branch, office of the Assistant Chief of Staff. Washington, D. C.

\section{COMMERCIAL STANDARDS}

CS No.

0-40. Conmercial standards and their value to business.

1-42. Clinical thermometers.

2-30. Mopsticks.

3-40. Stoddard solvent.

4-29. Staple porcelain (all-clay) plumbing fixtures.

5-46. Pipe nipples; brass, copper, steel and wrought-ion.

6-31. Wrought-iron pipe nipples. Superseded by CS5-46.
CS No.

7-29. Standard weight malleable iron or steel screwed unions.

8-41. Gage blanks.

9-3.. Builders' template hardware.

10-29. Brass pipe nipples. Superseded by C.S5-46.

11-41. Moisture regains of cotton yarns.

$12-48$. Fuel oils.

$13-4 t$. Dress patterns.

14-51. Bors' sport and dress shirt (woven fabrics) size measurements. 
CS No.

15-46. Men's pajama sizes (made from woven fabries ).

16-29. Wallpaper.

17-47. Diamond core drill fittings.

18-29. Hickory golf shafts.

19-32. Foundry patterns of wood.

20-49. Vitreous china plumbing fixtures.

21-39. Interchangeable ground-glass joints, stopcocks, and stoppers.

22-40. Builders' hardware (nontemplate) 23-30. Feldspar.

24-43. Screw threads and tap-drill sizes.

25-30. Special screw threads. Superseded by CS24-43.

26-30. Aromatic red cedar closet lining. 27-36. Mirrors.

28-46. Cotton fabric tents, tarpaulins and covers.

29-31. Staple seats for water-closet bowls

30-31. (Withdrawn).

31-38. Wood shingles.

32-31. Cotton cloth for rubber and pyroxylin coating.

33-43. Knit underwear (exclusive of rayon).

34-31. Bag, case, and strap leather.

35-49. Hardwood plywood.

36-33. Fourdrinier wire cloth.

$37-31$. Steel bone plates and screws.

38-32. Hospital rubber sheeting.

39-37. (Withdrawn).

40-32. Surgeons' rubber gloves.

41-32. Surgeons' latex gloves.

42-49. Structural fiber insulating board.

43-32. Grading of sulphonated oils.

44-32. Apple wraps.

45-48. Douglas fir plywood.

46-49. Hosiery lengths and sizes.

47-34. Marking of gold-filled and rolledgold-plate articles other than watchcases.

48-40. Domestic burners for Pennsylvania

49-34. Chip board, laminated chip board, and miscellaneous boards for bookbinding purposes.

50-34. Binders board for bookbinding and

51-35. Marking articles made of silver in combination with gold.

52-35. Mohair pile fabrics (100-percent mohair plain velvet, 100 -percent mohair plain frieze, and 50 -percent mohair plain frieze).

53-35. Colors and finishes for cast stone.

54-35. Mattresses for hospitals.

55-35. Mattresses for institutions.

56-49. Oak flooring.

57-40. Book cloths, buckrams, and impregnated fabries for bookbinding purposes except library bindings.

58-36. Woven elastic fabrics for use in overalls (overall elastic webbing)

59-44. Textiles-testing and reporting.

60-48. Hardwood dimension lumber.

61-37. Wood-slat venetian blinds.

62-38. Colors for kitchen accessories

63-38. Colors for bathroom accessories.

64-37. Walnut veneers.

65-43. Methods of analysis and of reporting fiber composition of textile products.

66-38. Marking of articles made wholly or

in part of platinum.

68-38. Liquid hypochlorite disinfectant, deodorant, and germicide.

69-38. Pine oil disinfectant

70-41. Phenolic disinfectant (emulsifying type) (published with CS71-41)

71-41. Phenolic disinfectant (soluble type) (published with CS70-41)

72-38. Household insecticide (liquid spray type).

73-48. Old growth Douglas fir, Sitka spruce and Western hemlock standard stock doors.
CS No.

74-39. Solid hardwood wall paneling.

75-42. Automatic mechanical draft oil burners designed for domestic installations.

76-39. Hardwood interior trim and molding.

77-48. Enameled cast-iron plumbing fixtures.

78-40. Ground-and-polished lenses for sun glasses (published with CS79-40).

79-40. Blown, drawn, and dropped lenses for sun glasses (published with CS78-40)

80-41. Flectric direction signal systems other than semaphore type for commercial and other vehicles subject to special motor vehicle laws (after market).

81-41. Adverse-weather lamps for vehicles (after market).

82-41. Inner-controlled spotlamps for vehicles (after market).

83-41. Clearance, marker, and identification lamps for vehicles (after market)

84-41. Electric tail lamps for vehicles (after market).

85-41. Electric license-plate lamps for ve hicles (after market).

86-41. Electric stop lamps for vehicles (after market).

87-41. Red electric warning lanterns.

88-41. Liquid burning flares.

89-40. Hardwood stair treads and risers.

90-49. Power cranes and shovels.

91-41. Factory-fitted Douglas fir entrance doors.

92-41. Cedar, cypress and redwood tank stock lumber.

93-50. Portable electric drills (exclusive of high frequency).

94-41. Calking lead.

95-41. Lead pipe.

96-41. Lead traps and bends.

97-42. Electric supplementary driving and passing lamps for vehicles (after market).

9s-42. Artists' oil paints.

99-42. Gas floor furnaces-gravity circulating type.

100-47. Porcelain-enameled steel utensils.

101-43. Flue-connected oil-burning space heaters equipped with vaporizing pot-type burners.

102- . (Reserved for "Diesel and fuel-oil engines.")

103-48. Rayon jacquard velour (with or without other decorative yarn).

104-49. Warm-air furnaces equipped with vaporizing type oil burners.

105-48. Mineral wool insulation for low temperatures.

106-44. Boys' pajama sizes (woven fabrics). 107-45. (Withdrawn.)

108-43. Treading automobile and truck tires.

109-44. Solid-fuel-burning forced-air furnaces.

110-43. Tire repairs-vulcanized (passenger, truck, and bus tires )

111-43. Earthenware (vitreous-g l a $\mathrm{z}$ e d) plumbing fixtures.

112-43. Homogeneous fiber wallboard

113-51. Oil-burning floor furnaces equipped with vaporizing pot-type burners.

114-43. Hospital sheeting for mattress protection.

115-44. Porcelain-enameled tanks for domestic use.

116-44. Bituminized-fibre drain and sewer pipe.

117-49. Mineral wool insulation for heated industrial equipment.

118-44. Marking of jewelry and novelties of silver.

(E) 119-45.1 Dial indicators (for linear measurements).

1 Where "(E)" precedes the CS number, it indicates an emergency commercial standard, drafted under war conditions with a view toward early revision. 
151-48. Body measurements for the sizing doors.
Vonen's slip sizes (woven fabrics).

121-45. Women's slip sizes (woven

$123-49$. Grading of diamond powder.

(E) 124-45.1 Master disks.

125-47. Prefabricated homes.

126-45. Tank-mounted air compressors.

127-45. Self-contained mechanically refrigerated drinking water coolers.

128-49. Men's sport shirt sizes-woven fabrics (other than those marked with regular neckband sizes).

129-47. Materials for safety wearing apparel.

130-46. Color materials for art education in schools.

131-46. Industrial mineral wool products, all types - testing and reporting.

132-46. Hardware cloth.

133-46. Woven wire netting.

134-46. Cast aluminum cooking utensils (metal composition).

135-46. Men's shirt sizes (exclusive of work shirts).

136-46. Blankets for hospitals (wool, and wool and cotton).

137-51. Size measurements for men's and boys' shorts (woven fabrics)

138-49. Insect wire screening.

139-47. Work gloves.

140-47. Testing and rating convectors.

141-47. Sine bars, blocks, plates, and fixtures.

142-47. Automotive lifts.

143-47. Standard strength and extra strength perforated clay pipe.

144-47. Formed metal porcelain enameled sanitary ware.

145-47. Testing and rating hand-fired hotwater supply boilers.

146-47. Gowns for hospital patients.

$147-47$. Colors for molded urea plastics.

148-50. Men's circular flat and rib knit rayon underwear.

149-48. Ttility type house dress sizes.

150-48. Hot rolled rail steel bars (produced from Tee-section rails). knit underwear industry). of apparel for infants, babies,

152-48. Copper naphthenate wood-preservative (spray, brush, dip application).

153-4S. Body measurements for the sizing of apparel for girls (for the knit underwear industry).

154- . (Reserved for "Wire rope.")

155-50. Body measurements for the sizing of boys' apparel (knit underwear, shirts, trousers).

156-49. Colors for polystyrene plastics.

157-49. Ponderosa pine and sugar pine plywood.

158-49. Model forms for girls' apparel.

159-49. Sun-glass lenses made of ground and polished plate glass, thereafter thermally curved.

160-49. Wood-fiber blanket insulation (for building construction).

161-49. "Standard grade" hot-dipped galvanized ware (coated after fabrication).

162-49. Tufted bedspreads.

163-49. Standard stock ponderosa pine windows, sash, and sereens.

164- . (Reserved for "Concrete mixers".)

165-50. Zinc naphthenate wood-preservative (spray, brush, dip application).

166-50. Size measurements for men's work trousers.

167-50. Automotive and general service copper tube.

168-50. Polystyrene plastic wall tiles, and adhesives for their application.

169-50. Galvanized ware fabricated from pregalvanized steel sheets.

170-50. Cotton flour bag (sack) towels.

171-50. Hardwood veneered doors.

$172-50$. Brass trim for water-closet bowls, tanks, and urinals (dimensional standards).

173-50. Heavy - duty alpha - cellulose - filled melamine tableware.

Notice.-Those interested in commercial standards with a view toward accepting them as a basis of everyday practice may secure copies of the above standards, while the supply lasts, by addressing the Commodity Standards Division, Office of Industry and Commerce, U. S. Department of Commerce, Washington 25, D. C.

1 Where "(E)" precedes the CS number, it indicates an emergency commercial standard drafted under war conditions with a view toward early revision. 